\title{
Nepal-China Bilateral Economic Cooperation Empowering Nepalese Economy
}

\author{
-Dr. Khom Raj Kharel* \\ - Dr. Yadav Mani Upadhyay* \\ - Dr. Suman Kharel*
}

\begin{abstract}
Bilateral economic cooperation is one of the means for improving economic, social and political relations between two countries. Nepal and China have been enjoying good neighborly respects and benefit since the establishment of diplomatic relations in 1955. Both countries behave a good neighborhood relations and enjoyed fruitful bilateral cooperation and mutual support and following the social and economic development activities by exchanging cooperation in the areas of trade, tourism, investment and connectivity, building human capital and infrastructure and deepening people to people relations is at the center of Nepal-China bilateral relations. Within Nepal and China, there are marvelous possibilities promoting socio-economic transformation and raising the living standard of people through the mutual cooperation in the areas of mutual interest. Cooperation under the Belt and Road Initiative (BRI) is of great significance for Nepal and China. The present study is conducted with the aim of examining the economic impact of bilateral economic cooperation between Nepal and China. The impact of bilateral cooperation with China in Nepalese economy has been analyzed in terms of FDI flows, trade between Nepal, China and economic assistance from China to Nepal and tourist arrivals from China over the period of 2000-2019 by applying simple statistical tools and simple linear regression model. The results show that there have been positive influences on Nepalese economy with bilateral economic cooperation of China.
\end{abstract}

Keywords: Bilateral relations- Cooperation-Impact-Nepal and China-Nepalese economy.

\section{Introduction}

China is one of the closest neighborhood countries and has been recognized as one of the biggest economic development supporter countries to Nepal. The economic and political relations of Nepal and China began with Tibet serving as the link. The $16^{\text {th }}$ and $17^{\text {th }}$ centuries were critical periods for the relation between Nepal and Tibet. During that period Tibet underwent an internal crisis in the competing Buddhist sects. Nepal took advantage of that situation to seize control of the vital border-pass areas through which most of the transHimalayan trade passed. In early $18^{\text {th }}$ century, China established a presence in Tibet and became for the first time, an important factor in Himalayan area politics.

* Dr. Kharel is an Associate Professor of Economics, Saraswati Multiple Campus, TU, Nepal

* Dr. Upadhaya is an Assistant Professor of Economics, Saraswati Multiple Campus, TU, Nepal

* Dr. Kharel is an Associate Professor of Rural Development, TU, Nepal 
After 1950s, China began to provide economic aid and technical assistance to other countries and gradually expanded the scope of aid. Since 1970s, China has adopted the reform and opening-up policies in its economy; and it developed rapidly, with the overall national strength growing notably. China has been doing its best to provide foreign aid, to help recipient countries to strengthen their self-development capacity, enrich and improve their people's livelihood, promote their economic growth and social progress. China has consolidated friendly relations and economic and trade cooperation with other developing countries, promoted South-South cooperation and contributed to the common development of mankind (MoFA,2014).

There are various possibilities of sharing advantages from the economic cooperation between Nepal and China. The focus of this study is to analyze the economic impact of bilateral economic relations on Nepalese economy in terms of Chinese assistance, FDI, tourism and trade.

\section{Brief of Nepal-China Economic Cooperation}

Nepal and China formalized their relations on $1^{\text {st }}$ August 1955 by establishing diplomatic relations. China-Nepal relations have been addressed as friendliness, understanding, mutual cooperation and respect for each other. Economic cooperation of Nepal-China dates back to the formalization of bilateral relations in 1950s. The first agreement between Nepal and China on economic aid was signed in October 1956. From the mid-1980s, Chinese Government has been committing grant assistance to Nepal under Economic and Technical Cooperation Program to implement mutually acceptable development projects. Chinese assistance to Nepal falls into three categories: Grants (Aid Grantis), Interest free loans and concessional loans. The Chinese financial and technical assistance to Nepal has significantly contributed to Nepal's development efforts in the areas of infrastructure building, industrialization process, human resources development, health, education, water resources, sports, military empowerment etc. Existing Projects under Chinese assistance are listed in Table 1.

\begin{tabular}{|l|l|}
\hline \multicolumn{2}{|c|}{ Table 1: Major Chinese Projects in Nepal } \\
\hline S.N. & Existing Projects \\
\hline 1. & Upper Trishuli Hydropower Project-power station and Transmission Line Projects \\
\hline 2. & Food/Material Assistance in Northern 15 bordering Districts \\
\hline 3. & Kathmandu Ring Road Improvement Project \\
\hline 4. & Larcha (Tatopani) and Timure (Rasuwagadi) Frontier Inspection Station Project \\
\hline $\mathbf{5 .}$ & Pokhara International Regional Airport \\
\hline 6. & Upgradation of Syaprubensi-Rasuwagadhi Road \\
\hline 7. & Upgradation of Civil Service Hospital \\
\hline 8. & $\begin{array}{l}\text { Upgradation of Kodari Highway and Restoration of Bordering Bridges at Kodari } \\
\text { and Rasuwagadi }\end{array}$ \\
\hline
\end{tabular}


The new adventures for bilateral cooperation in the mutually agreed areas has been opened after the signing of the Memorandum of Understanding (MoU) on Cooperation under the Belt and Road Initiative (BRI) on 12 May 2017. It was believed that MoU could promote mutually beneficial cooperation between two countries in different areas like economy, technology, culture and environment. Similarly, the MoU aims at promoting cooperation on policy exchanges, infrastructure connectivity, trade connectivity, financial integration and connectivity of people. The Government of China had provided substantial and spontaneous support in search, relief and rescue efforts of Nepal following the devastating earthquakes of 2015. As being a biggest supporter country, China has declared to provide more than three billion Yuan for Nepal's reconstruction to be mobilized by the mutually selected 25 major projects in the period of 2016-2018. Similarly, Nepal and China have signed three separate bilateral agreements on economic and technical cooperation within 2016-2018 for providing one billion Yuan in terms of Chinese grants to Nepal for post-disaster reconstruction projects (MoA, 2021).

\section{Literature Review}

China has been extending sympathy, support and assistance after 1950s. Nepal has been also supporting one China policy and not allowing anti-Chinese activities in Nepalese soil. The sovereignty and territorial integrity of China toward Taiwan and Tibet is respected by Nepal. The scope of mutual relationship between Nepal and China has been becoming broader but it should be enhanced further in coming days (Prasad, 2015). Fukumoto (2000) analyzed the effects of regional cooperation to all Northeast Asian countries. The economic benefits were analyzed based on economic and technical cooperation activities which reflected in terms of economic benefits to all countries. To increase the consequence in regional trade, the economic cooperation could stimulate and the better economic relations could enhance greater political stability among the nations. However, increasing interchange based on purely economic benefits plays an important role in constructing better political relations.

The dynamic economic benefits from the regional cooperation effected on trade creation and trade diversification together having revenue and welfare. The study has focused on enhancing economic growth by increasing intra-regional trade between the member countries which positively impact on economic and human development (Rahman \& Amin,2009). For the overall economic activities of the country, bilateral economic cooperation represents a small portion. Economic cooperation was further stimulated by the adoption of neo-liberal economic development strategies by the two countries. The economic relationship between Chile and Argentina particularly in the financial sphere which was reflected of that new relationship. Significant progress on economic cooperation 
could only be made after both countries adopted the view that national security dependent upon maintaining the status quo (Mares, 2000).

Toward the Comprehensive Economic and Trade Agreement (CETA), the European Commission has negotiated with a view of establishing a state of the art which privileged economic relationship with Canada. CETA was expected to significantly improve business opportunities for European companies in Canada.CETA contains a wide range of provisions that would have direct positive impact on the ability of EU and Canadian companies to engage in closer economic relations-notably commitments on the liberalization of tariffs, investment or services, increased access to each other's public procurement markets, disciplines on intellectual property rights, geographical indications, conformity assessment, subsidies and so on (European Union, 2017).

It has been believed that India and Sri Lanka could grasp significant benefits through greater cooperation of service sectors. Both governments recognized that effects were formalized and institutionalized cooperation in the form of CEPA in 2005. Mukherji and Iyengar (2013) suggested the scope for extension of cooperation for goods, investment and services computing indices with negative lists and identifying potential investment on the basis of bilateral similar products trade.

The bilateral issues of China and US prevailed that the US government interacts with China bilaterally in two basic ways as proactively through US policies to encourage economic reform and responsible integration into global economy. The administration regards technical assistance as the primary channel through which it could influence economic reform in China. Similarly, bilateral inter-governmental relations were dominated by a second track of reactive trade conflict, largely a function of China's rapid growth, partially reformed economic systems and the complainant driven US trade policy making system (Noland,1996). Rana and Karmacharya (2014) highlighted that improved connectivity within Nepal and cross-border connectivity with its neighbors in South Asia and China. Verico (2020) viewed the macroeconomic indicators comparison, Indonesia and Australia could find at different level. The paper identified the need to be increased their economic benefits which revealed that they could share mutual benefits and sustainable economic relations.

Bi (2021) highlighted that the increasing close economic cooperation between China and ASEAN has promoted the growth of bilateral common interests and laid a solid material foundation for development of political relations. For promoting regional cooperation, China and ASEAN had supported and cooperated with each other and gained many successful experiences. Rahman et al (2020) has remarked that the Indo-Pacific could become a powerful regional block if the South and Southeast Asia could be linked through 
the connectivity, maritime link, improving trade facilitation and other required networks which could reduce trade costs. Yadav (2021) remarked the Sino-Nepalese relationship has predicted that foreign direct investment deals capacity-building measures and diplomatic support international forums.

The trade transaction cost is one of the major trading barriers improvement in infrastructure and connectivity that leads to less trade transportation costs should be a necessary step to realize Indo-Pacific trade potential. There has been great position of Chinese investment and financing for boosting Nepal's infrastructure goals, for grasping the Chinese investment and financing, Nepal needs to create attractive environment for success. The political leadership must put aside its differences with opposition parties and work together to user a new era of infrastructure propelled development. By reviewing the different research papers, it has been found that there is significant contribution and economic impact of bilateral economic cooperation in Nepalese economy. There has been economic impact of bilateral economic cooperation on assistance, trade, FDI and tourism in Nepal. The research papers have been conducted different studies on bilateral and multilateral economic cooperation and relations of different country context. In the context of economic impact of bilateral economic cooperation between Nepal and China, there have not been conducted comprehensive studies. There have been conducted many studies toward the economic impact of bilateral economic relations as well regional relations on economy in different countries, in case of Nepal and China such bilateral comprehensive study has not been done.

\section{Method and Data}

This study is based on secondary data and descriptive and analytical research design is applied to analyze data. All analysis and discussion have been based on published source of secondary data such as Economic Surveys (2000/01-2019/20), Ministry of Finance, Ministry of Tourism, Department of Industry, Trade Promotion Center, Nepal Rastra Bank, Central Bureau of Statistics (CBS) and other different associations which are related with relations of Nepal and China. The economic impact of bilateral economic cooperation has been analyzed in terms of tourist arrivals from China, FDI from China and trade between Nepal and China by using descriptive statistics such as table and line graph are also used to explain the data. The economic impact of bilateral economic cooperation is measured in terms of foreign exchange earnings with total tourist arrivals from China and Chinese FDI of industrial GDP of Nepal by using simple regression model. 


\section{Model Specification}

Regression equations are used to estimate of Chinese tourist arrivals on foreign exchange earnings of Nepal and the economic impact of Chinese FDI on industrial GDP of the country.

The impact of Chinese tourist arrivals (CTA) on foreign exchange earnings is estimated by: FEEs $=\alpha_{0}+\beta_{1} C T A+\varepsilon_{t}$

Where, FEE is foreign exchange earnings, CTA istourist arrivals from China in Nepal. The $\alpha_{0}$ is constant, $\beta_{1}$ is coefficientparameter, $\mathcal{E}$ is the error term.

The impact of Chinese FDI (CFDI) on industrial GDP of Nepal (IGDP) is estimated by: $I G D P=\alpha_{0}+\beta_{1} C F D I+\varepsilon_{t}$

\section{Results and Discussion}

\section{Nepal and China Trade Relations}

The bilateral relationship of Nepal with China has established since time immemorial whereas the officially justified by the landmark Sino-Nepal Peace and Friendship treaty in 1960. Trade and Payments Agreement was signed between Nepal and China on May 31, 1974. The agreement had initiated and promoted the trade between the countries and open the ports for transaction of goods through Chinese ports. That Trade and Payments Agreements was followed and signed on November 22, 1981 between Nepal and China which was the replacement of trade agreement of 1974 to be enforced for three years with the purpose of further developing the friendship between two countries and strengthening the economic and trade relations. The payments of trade overseas between the two countries should be made in freely convertible currency (Department of Customs, Tripureshwor, Kathmandu, Nepal 2014).

The bilateral relation is further exemplified through a series of engagements post-2015. Nepal and China has also signed trade and transit agreement in 2016. Subsequently, Nepal became one of the first countries to join China's Belt and Road Initiative (BRI), the latter's trillion dollar plus to expand its global influence. Besides this, Nepal and China have been negotiating railroads and transmission line projects after 2018. Trade and other related matters treaty was signed on July 10, 2002 for further development of friendly and good neighborly relations. The agreement remained in force for ten years and can be renewed automatically further for same period unless it is terminated by either party. Nepal and China have signed a Transit Trade Treaty and Nine other pacts March 22, 2016 for using northern port facility, building a regional international airport in Pokhara by considering the best possibilities with signing a bilateral free trade agreement as well as searching gas and oil reserves in Nepal. 


\section{Trade Status of Nepal with China}

China is the second largest trade partner country of foreign trade of Nepal. Nepal's foreign trade with China has been increasing after 2006s. The ratio of foreign trade of Nepal with China ranges from 7.41 percent to 13.70 percent during the study periods. The foreign trade of Nepal with China has been shown in the Table-2:

Table-2: Trade Relations of Nepal and China from 2006/07-2019/20. (Rs. in ten Million)

\begin{tabular}{|l|c|c|c|c|c|c|}
\hline Year & $\begin{array}{c}\text { Total } \\
\text { Trade }\end{array}$ & $\begin{array}{c}\text { Trade } \\
\text { with } \\
\text { China }\end{array}$ & $\begin{array}{c}\text { Ratio to } \\
\text { Total Trade } \\
\mathbf{( \% )}\end{array}$ & $\begin{array}{c}\text { Import } \\
\text { from } \\
\text { China }\end{array}$ & $\begin{array}{c}\text { Export to } \\
\text { China }\end{array}$ & $\begin{array}{c}\text { Trade } \\
\text { Balance }\end{array}$ \\
\hline $2006 / 07$ & 25407.77 & 1883.64 & $7.41 \%$ & 1819.82 & 63.82 & -1756.00 \\
\hline $2007 / 08$ & 28120.40 & 2299.22 & $8.17 \%$ & 2225.58 & 73.64 & -2151.94 \\
\hline $2008 / 09$ & 35216.70 & 3470.08 & $9.85 \%$ & 3285.29 & 184.79 & -3100.50 \\
\hline $2009 / 10$ & 43515.90 & 3959.62 & $9.10 \%$ & 3921.82 & 37.80 & -3884.02 \\
\hline $2010 / 11$ & 46051.40 & 4638.20 & $10.07 \%$ & 4563.60 & 74.60 & -4489.00 \\
\hline $2011 / 12$ & 53592.90 & 5391.07 & $10.06 \%$ & 5292.50 & 98.57 & -5193.93 \\
\hline $2012 / 13$ & 63365.80 & 6453.70 & $10.20 \%$ & 6245.10 & 208.60 & -6036.60 \\
\hline $2013 / 14$ & 80635.70 & 7615.90 & $9.40 \%$ & 7331.90 & 284.10 & -7047.80 \\
\hline $2014 / 15$ & 86000.30 & 10239.60 & $13.90 \%$ & 10016.60 & 223.00 & -9793.70 \\
\hline $2015 / 16$ & 84371.60 & 11737.60 & $13.90 \%$ & 11569.40 & 168.20 & -11401.30 \\
\hline $2016 / 17$ & 106316.20 & 12894.50 & $12.10 \%$ & 12724.50 & 170.10 & -12554.40 \\
\hline $2017 / 18$ & 132646.30 & 16242.5 & $12.20 \%$ & 15998.70 & 243.80 & -15754.90 \\
\hline $2018 / 19$ & 151564.50 & 20763.7 & $13.70 \%$ & 20551.9 & 211.00 & -20340.90 \\
\hline $2019 / 20$ & 129450.8 & 18311.1 & $14.10 \%$ & 18192 & 119.1 & -18072.90 \\
\hline
\end{tabular}

Source: Trade Promotion Center (2019/20) and Economic Survey 2019/20.

Table-2 represents the total volume of foreign trade, total trade with China, import trade from China, export trade to China and trade balance of trade between Nepal and China from 2006/07 to 2018/19. Figure 1 portrays the trend of Nepal's total and China-specific trade.

Figure-1: Total Volume of Trade and Total Trade with China 


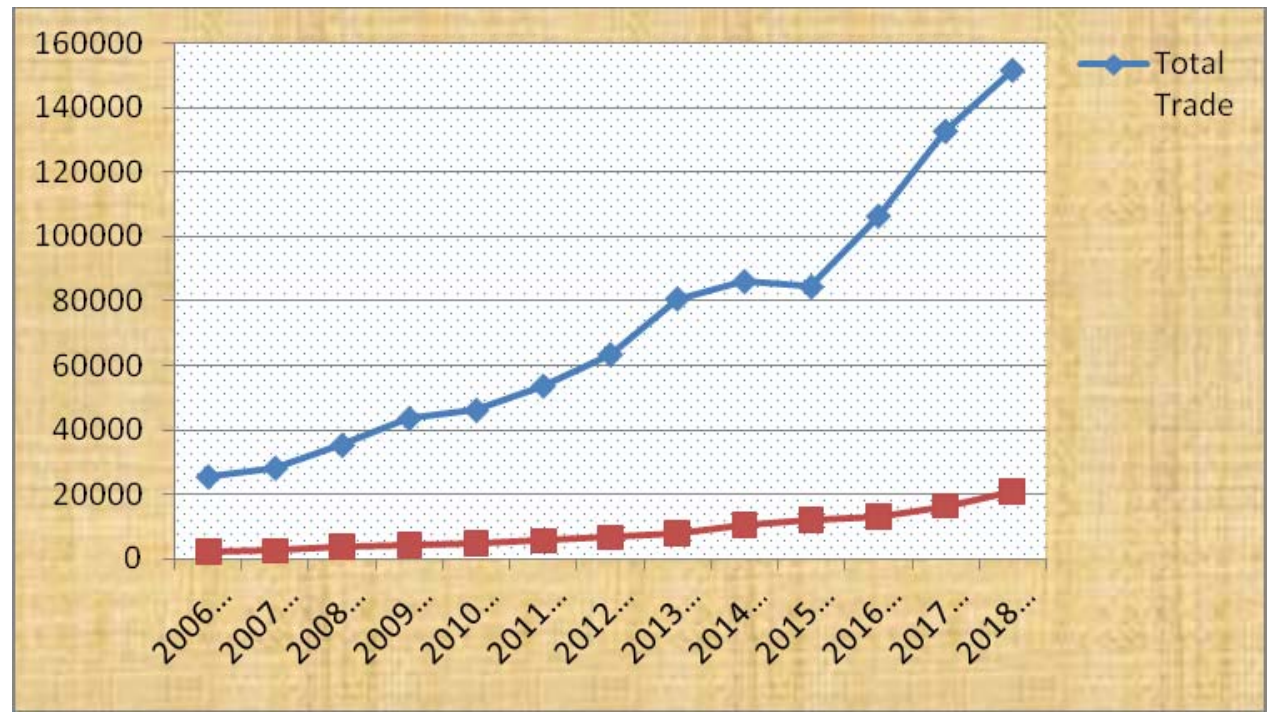

Figure-1 depicts the total volume of foreign trade and total trade with China. The trends of total volume of foreign trade and total trade with have been increasing during the study periods. Figure-2 depicts the total trade, import trade, export trade and trade balance of Nepal and China from 2006/07 to 2018/19.

\section{Figure-2: Total Trade, Import Trade, Export Trade \& Trade Balance between Nepal and} China

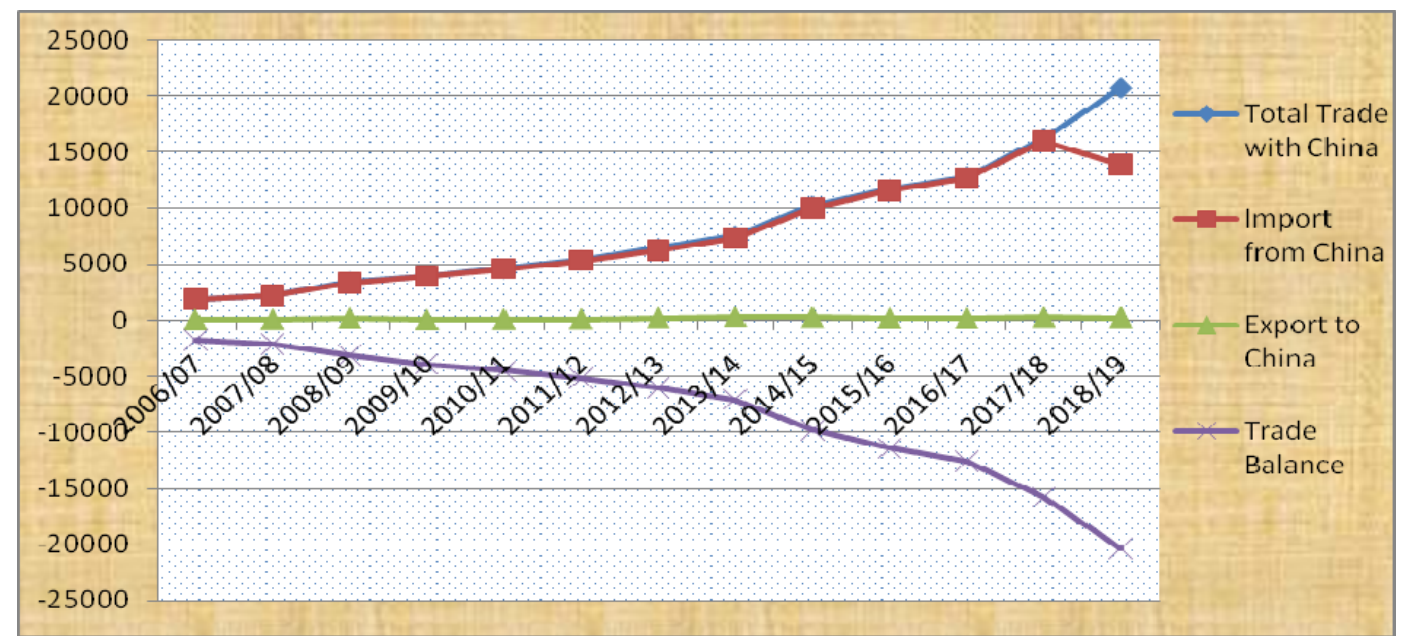

The export trade of Nepal to China is insignificant in comparison to import trade from China. The trade deficit of Nepal has been expanding during the study period.

\section{Foreign Direct Investment from China to Nepal}

Foreign direct investment of Nepal has one of the major components of economic development and prosperity of Nepal. The flow of FDI of Nepal has increased after 1990s 
while Nepal introduced the Foreign Investment and Technology Transfer Act (FITTA) in 1992. The liberal and open economic policy invites the foreign capital of Nepal. After 2000s, the trends of Chinese FDI have significantly increased. Since last decades, Chinese FDI stands the biggest position of Nepal (Table-3).

Table -3: FDI of China and Total FDI of Nepal from 2000-2019. (Rs. in Ten Million)

\begin{tabular}{|l|c|c|c|c|c|c|}
\hline \multirow{2}{*}{ Year } & \multicolumn{3}{|c|}{ China } & Total Projects & Total FDI & Employme \\
\cline { 2 - 4 } & $\begin{array}{c}\text { Project } \\
\text { s }\end{array}$ & FDI & $\begin{array}{c}\text { Employmen } \\
\text { t }\end{array}$ & & & \\
\hline $2000 / 01$ & 15 & 70.53 & 2315 & 96 & 300.26 & 6880 \\
\hline $2001 / 02$ & 12 & 16.25 & 597 & 77 & 120.96 & 3731 \\
\hline $2002 / 03$ & 12 & 16.05 & 373 & 73 & 179.03 & 3543 \\
\hline $2003 / 04$ & 16 & 18.17 & S143 & 78 & 276.48 & 2154 \\
\hline $2004 / 05$ & 12 & 17.65 & 421 & 63 & 163.58 & 5559 \\
\hline $2005 / 06$ & 21 & 18.04 & 915 & 116 & 260.63 & 7358 \\
\hline $2006 / 07$ & 38 & 33.50 & 1476 & 188 & 318.60 & 7389 \\
\hline $2007 / 08$ & 39 & 44.87 & 1997 & 212 & 981.06 & 10709 \\
\hline $2008 / 09$ & 71 & 115.05 & 4945 & 230 & 625.33 & 11091 \\
\hline $2009 / 10$ & 58 & 71.57 & 2791 & 170 & 909.18 & 7822 \\
\hline $2010 / 11$ & 69 & 118.74 & 3066 & 209 & 1005.07 & 10887 \\
\hline $2011 / 12$ & 77 & 98.60 & 3326 & 227 & 714.08 & 9050 \\
\hline $2012 / 13$ & 97 & 277.18 & 4943 & 317 & 1981.87 & 16569 \\
\hline $2013 / 14$ & 119 & 730.94 & 4620 & 306 & 2010.74 & 11762 \\
\hline $2014 / 15$ & 152 & 431.83 & 5803 & 367 & 6740.00 & 13072 \\
\hline $2015 / 16$ & 128 & 629.18 & 5666 & 346 & 1522.53 & 11198 \\
\hline $2016 / 17$ & 184 & 632.67 & 5537 & 400 & 1520.60 & 11842 \\
\hline $2017 / 18$ & 159 & 4470.19 & 6239 & 393 & 5371.61 & 13601 \\
\hline $2018 / 19$ & 158 & 1187.20 & 7056 & 336 & 2417.94 & 14016 \\
\hline $2019 / 20 *$ & 176 & 2555.97 & 8966 & 227 & 3803.03 & 10753 \\
\hline Total & $\mathbf{1 6 1 3}$ & $\mathbf{1 1 5 5 4 . 9 7}$ & $\mathbf{7 1 1 9 5}$ & $\mathbf{4 4 3 1}$ & $\mathbf{3 1 2 2 2 . 5 8}$ & $\mathbf{1 8 8 9 8 6}$ \\
\hline
\end{tabular}

\section{Source: Department of Industry, 12/17/2020}

Table-3 depicts the total FDI of Nepal and FDI from China from 2000/01 to 2019/20. There are all together 1,613 Chinese projects under which Chinese investment stands Rs. 11554.97 ten million which generated 71,195 employment opportunities during the study periods. Similarly, there are all together 4,431 FDI projects under which the total FDI is Rs. 31222.58 which generated 1 lakh 88 thousand 986 employment opportunities during the study period. 


\section{Figure-3: Total FDI of Nepal and FDI from China}

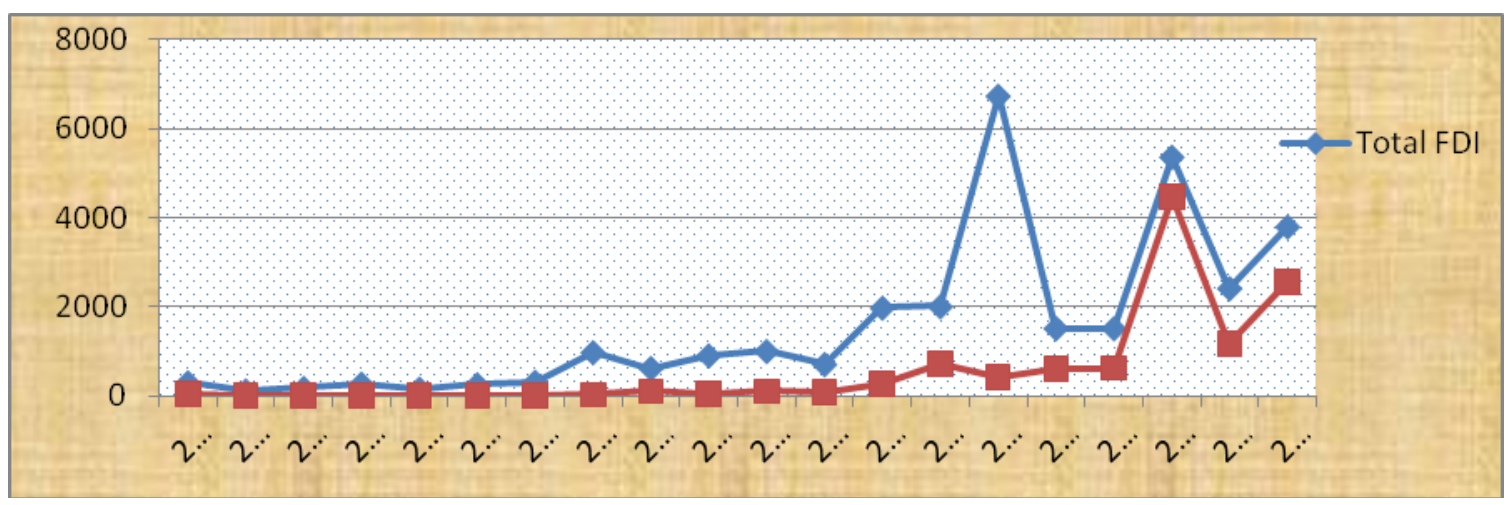

There has been deviation of FDI in different time periods. The highest FDI was in 2014/15 and lowest FDI was 2001/02. Similarly, the highest FDI from China was in 2017/18 and the lowest FDI was in 2019/20.

\section{Figure-4: Total FDI Projects and Chinese FDI Projects}

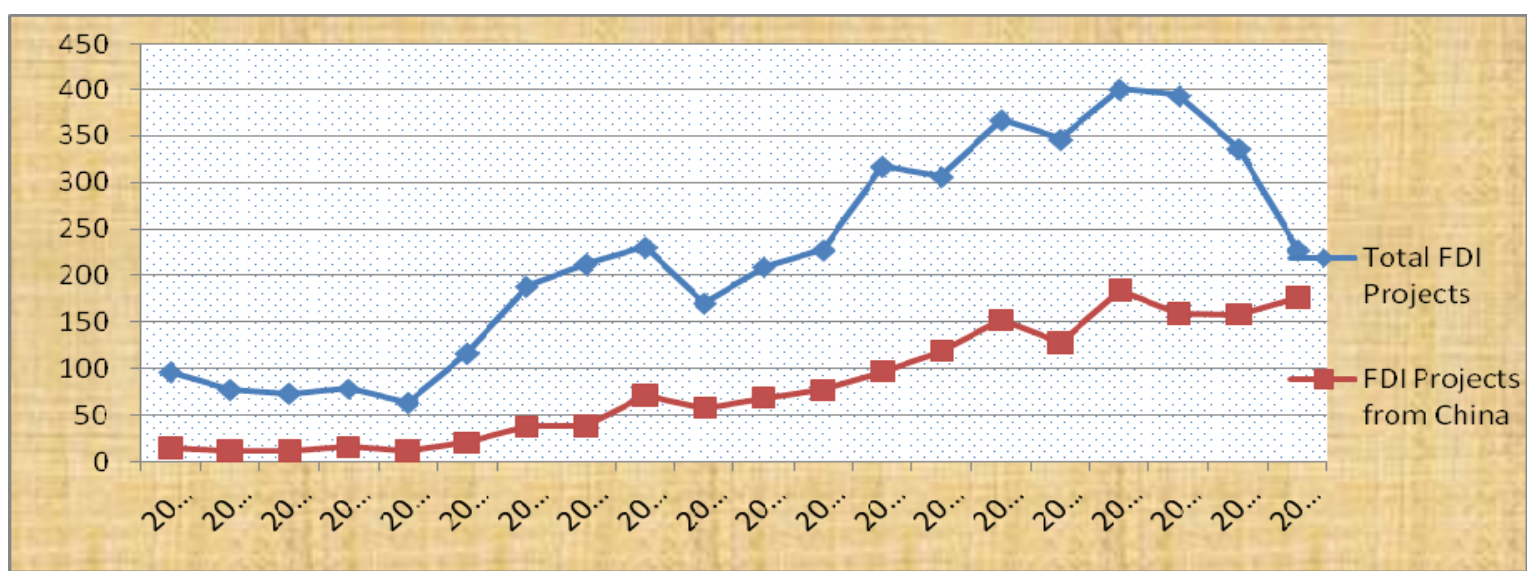

Figure-4 depicts the total FDI projects and total Chinese projects of Nepal which indicate increasing trends in the study periods.

Table-4: Top FDI Volume Countries to Nepal upto 2019/20 (Rs. in Ten Million)

\begin{tabular}{|l|l|l|l|}
\hline Country & Projects & FDI (Rs.) & Employment \\
\hline China (Mainland) & 1839 & 16758 & 85694 \\
\hline India & 802 & 9817 & 736464 \\
\hline U.K. & 205 & 1864 & 13455 \\
\hline USA & 422 & 1487 & 18848 \\
\hline South Korea & 360 & 1273 & 11954 \\
\hline Singapore & 53 & 622 & 3553 \\
\hline UAE & 23 & 376 & 1877 \\
\hline Mauritius & 11 & 343 & 1055 \\
\hline
\end{tabular}




\begin{tabular}{|l|l|l|l|}
\hline Canada & 47 & 334 & 2478 \\
\hline Japan & 275 & 323 & 10419 \\
\hline Others & 1144 & 2585 & 49994 \\
\hline Total & $\mathbf{5 , 1 8 1}$ & $\mathbf{3 5 , 7 8 1}$ & $\mathbf{2 , 7 2 , 7 9 1}$ \\
\hline
\end{tabular}

Source: M of, Economic Survey,2020/21.

Table-4 represents the FDI projects and investment of top ten counties in Nepal upto 2019/20.China stands the first rank in projects and investment and India stands second rank in both parameters. Similarly, the USA stands third position in projects but South Korea stands the third position from the side of investment. Till the date, there are altogether 4 thousand 5 hundred 65 FDI projects under which total investment depicts Rs.33693.52 ten million generating 1,93,934 employment opportunities from the existing FDI in Nepal.

\section{Figure-5: Project from Top FDI Volume Countries upto 2019/20}

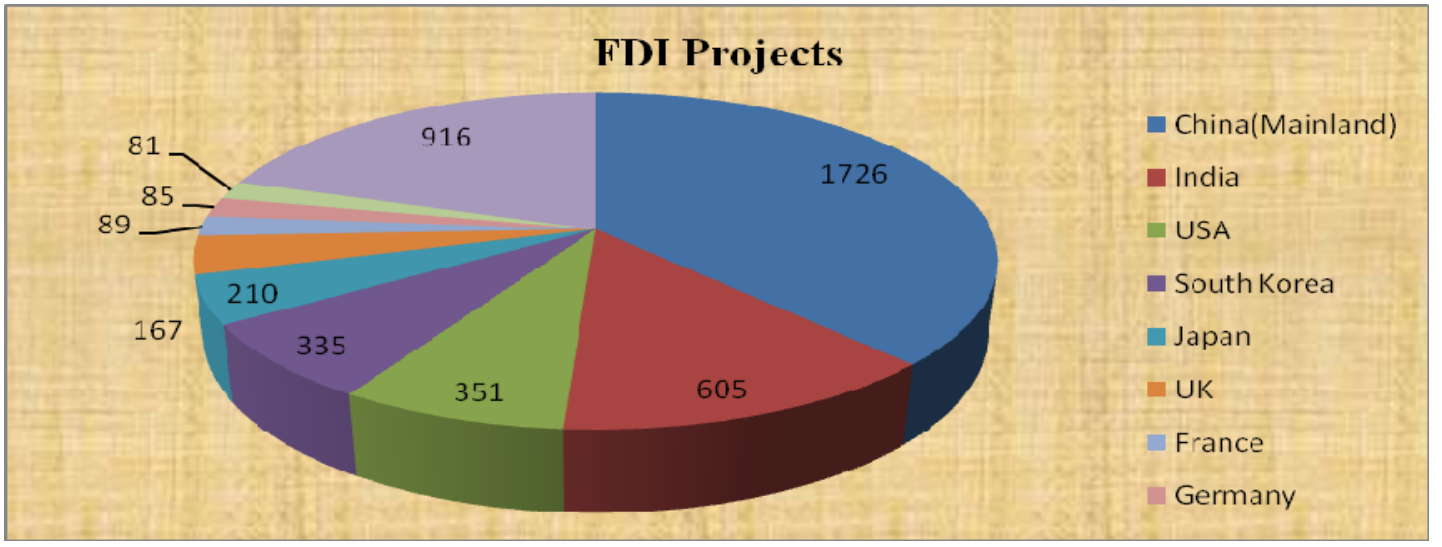

Figure-5 depicts the status of FDI projects of top countries up to 2019/20. China ranks the highest position of FDI in Nepal and India stands the second position.

Figure-6: Top FDI Volume Countries' Share in Nepal upto 2019/20

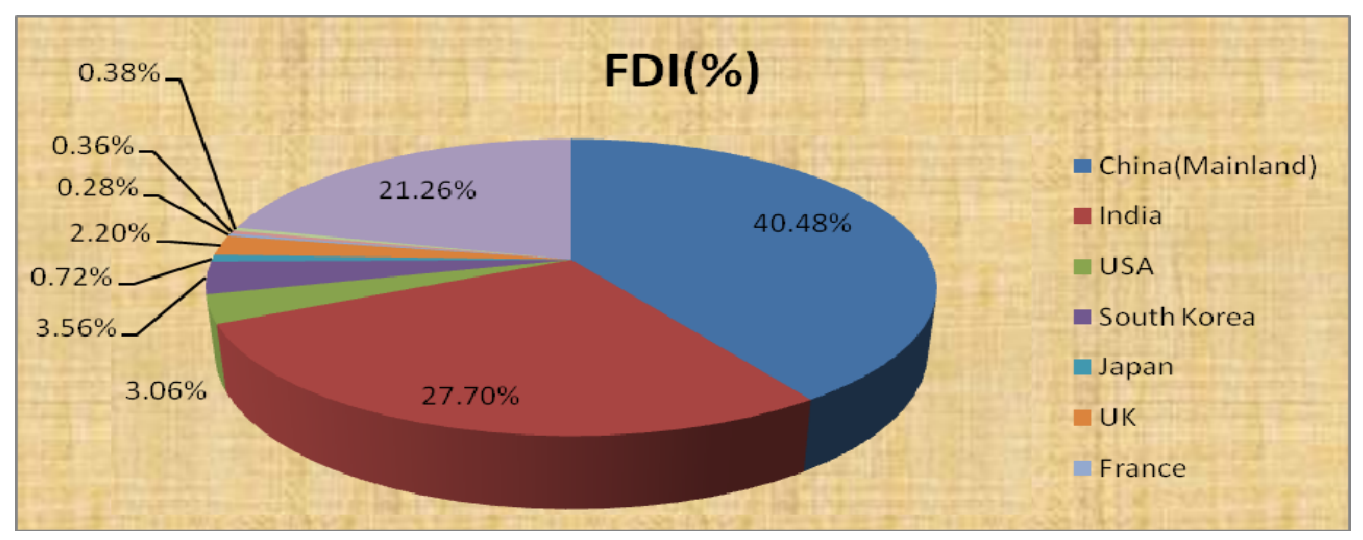


Figure-6 depicts FDI of top countries in Nepal. Chinese FDI is the biggest investment which covers 40.48 percent and Indian FDI stands second biggest which is 27.70 percent as well.

\section{Tourism Relations of Nepal and China}

Tourism industry is one of the most potential areas for economic development of Nepal. By developing tourism industry, Nepal can boost its economy with small investment. China is the second tourist arrival country of Nepal. After 2000s, the flow of Chinese tourist arrivals has been increasing (Table-5).

Table-5: Total Tourist Arrivals (TTAs) \& Tourist Arrivals from China from 2006/072019/20.

\begin{tabular}{|l|c|c|c|c|c|}
\hline Year & $\begin{array}{c}\text { Total } \\
\text { Tourist } \\
\text { Arrivals }\end{array}$ & $\begin{array}{c}\text { Chinese } \\
\text { Tourists }\end{array}$ & $\begin{array}{c}\text { Ratio to } \\
\text { TTAs(\%) }\end{array}$ & $\begin{array}{c}\text { Foreign } \\
\text { Exchange } \\
\text { Earnings }\end{array}$ & $\begin{array}{c}\text { \% of FFEs } \\
\text { to GDP }\end{array}$ \\
\hline $2006 / 07$ & 383926 & 17538 & 4.57 & 1020.50 & $1.4 \%$ \\
\hline $2007 / 08$ & 526705 & 28618 & 5.43 & 1865.30 & $2.3 \%$ \\
\hline $2008 / 09$ & 500277 & 35166 & 7.03 & 2796.00 & $2.8 \%$ \\
\hline $2009 / 10$ & 509956 & 32272 & 6.33 & 2813.90 & $2.4 \%$ \\
\hline $2010 / 11$ & 602867 & 46360 & 7.69 & 2461.10 & $1.8 \%$ \\
\hline $2011 / 12$ & 736215 & 61917 & 8.41 & 3070.40 & $2.0 \%$ \\
\hline $2012 / 13$ & 803092 & 71861 & 8.95 & 3421.10 & $2.0 \%$ \\
\hline $2013 / 14$ & 797616 & 113173 & 14.19 & 4637.50 & $2.4 \%$ \\
\hline $2014 / 15$ & 790118 & 123805 & 15.67 & 5342.90 & $2.5 \%$ \\
\hline $2015 / 16$ & 538970 & 66984 & 12.43 & 4176.50 & $1.9 \%$ \\
\hline $2016 / 17$ & 753002 & 104005 & 13.81 & 5852.70 & $2.2 \%$ \\
\hline $2017 / 18$ & 958532 & 104664 & 10.92 & 6852.20 & $2.3 \%$ \\
\hline $2018 / 19$ & 1173072 & 153633 & 13.10 & 7537.40 & $2.2 \%$ \\
\hline $2019 / 20$ & 1197191 & 169543 & 14.16 & 6088.5 & $1.5 \%$ \\
\hline
\end{tabular}

Source: Economic Survey 2019/20.

Table-5 states that the flow of Chinese tourist arrivals of Nepal from 2006/07 to 2019/20. The trend of Chinese tourist arrivals has been increasing during the study period. China stands 4.57 to 14.16 percent of total tourist arrivals of Nepal during the study periods.

\section{Figure-7: Total Tourist Arrivals and Tourist Arrivals from China}




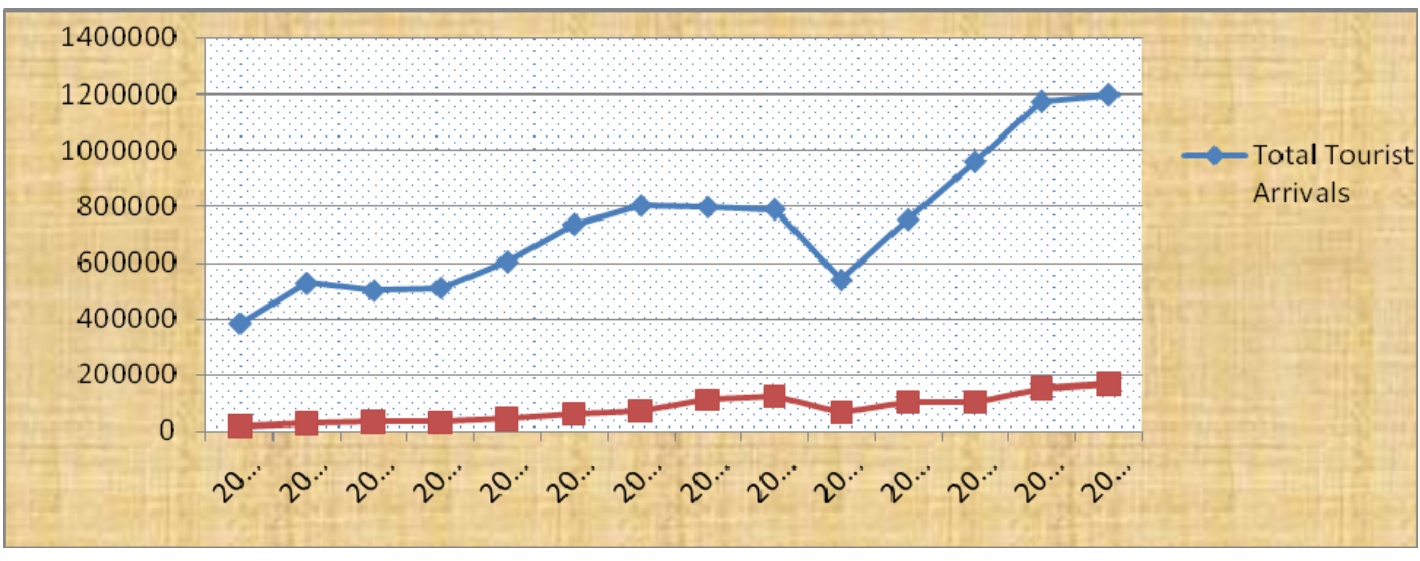

Figure-7 depicts the total tourist arrivals of Nepal and tourist arrivals from China from $2006 / 07$ to $2019 / 20$. The arrival of Chinese tourists is in increasing trend. The trend shows that China is one of the largest potential countries of tourist arrivals of Nepal. Nepal needs improvement in tourism facilities to attract large number of Chinese tourists. The tourism economy of Nepal has been contribution a substantial proportion to GDP of Nepal. The foreign exchange earnings from tourism industry has significantly increased during the study period.

\section{Relationship between Tourist Arrivals (TAs) from China and Total Foreign Exchange Earning (FEEs)}

Nepal earns foreign exchange from Chinese tourists visiting to Nepal. The regression estimates are given in Table 6.

Table-6: Effects of Tourist Arrivals (TAs) of China on Foreign Exchange Earnings from Tourism Sector

\begin{tabular}{|c|c|c|c|c|c|}
\hline \multicolumn{6}{|c|}{ Regression Statistics } \\
\hline \multicolumn{2}{|l|}{ Multiple R } & R Square & $\begin{array}{ll}\text { Adjusted } & \text { R } \\
\text { Square } & \end{array}$ & $\begin{array}{l}\text { Standard } \\
\text { Error }\end{array}$ & $\begin{array}{l}\text { Observation } \\
\text { s }\end{array}$ \\
\hline \multicolumn{2}{|l|}{0.908183801} & 0.824797817 & 0.810197635 & 856.7444149 & 14 \\
\hline & $d f$ & $S S$ & $M S$ & $F$ & $\begin{array}{l}\text { Significance } \\
F\end{array}$ \\
\hline Regression & 1 & 41465967.13 & 41465967.13 & 56.49229719 & $7.07925 \mathrm{E}-06$ \\
\hline Residual & 12 & 8808131.909 & 734010.9925 & & \\
\hline \multirow[t]{2}{*}{ Total } & 13 & 50274099.04 & & & \\
\hline & $\begin{array}{l}\text { Coefficient } \\
S\end{array}$ & $\begin{array}{l}\text { Standard } \\
\text { Error }\end{array}$ & $t$ Stat & P-value & Lower 95\% \\
\hline Intercept & 1146.7415 & 459.1800205 & 2.497368108 & 0.0280505 & 146.2742194 \\
\hline $\begin{array}{l}\text { Chinese } \\
\text { Tourists }\end{array}$ & 0.0370785 & 0.004933187 & 7.516135789 & $7.07925 \mathrm{E}-06$ & 0.026330014 \\
\hline
\end{tabular}

Source: Calculated by Author based on Table-5. 
Table-6 depicts that there is significant relationship between of total tourist arrivals of China and total foreign exchange earnings. This study finds that increase in tourist arrivals from China has contributed to foreign exchange earnings of Nepal. The regression analysis is statistically significant $\left(\mathrm{R}^{2}=0.824, \mathrm{p}<0.05\right)$. It is significant at 5 percent. These results indicate that the total tourist arrivals from China has influenced in increase in foreign exchange earning of Nepal.

\section{Economic Impact of Chinese FDI on Industrial GDP}

There has been significant contribution of Chinese FDI in industrial development of Nepal. The industrial investment boosts raising gross domestic product (GDP) and economic growth of Nepal. Similarly, there is significant contribution of tourism economy on national economy. Total tourist arrivals of Nepal induce employment, foreign exchange earnings, GDP and other socio-economic sectors. There has been significant contribution of Chinese FDI on industrial development of Nepal. The regression result on the effect of Chinese FDI on Nepal's industrial GDP is given in Table 7.

Table-7: Effect of Chinese FDI on Nepal's Industrial GDP

\begin{tabular}{|c|c|c|c|c|c|}
\hline \multicolumn{7}{|c|}{ Regression Statistics } \\
\hline \multicolumn{2}{|c|}{ Multiple R } & R Square & Adjusted R Square & S.Error & Observations \\
\hline 0.760374367 & 0.578169177 & 0.554734132 & 19849.51687 & 20 \\
\hline & df & SS & MS & F & Significance F \\
\hline Regression & 1 & 9720509124 & 9720509124 & 24.67113506 & $9.9719 \mathrm{E}-05$ \\
\hline Residual & 18 & 7092059762 & 394003320.1 & & \\
\hline Total & 19 & 16812568886 & & & \\
\hline & Coefficients & S. Error & t Stat & P-value & Lower 95\% \\
\hline Intercept & 41206.87238 & 5044.15851 & 8.169226304 & $1.81664 \mathrm{E}-07$ & 30609.48859 \\
\hline CFDI & 20.60481855 & 4.1483389 & 4.967004636 & $9.9719 \mathrm{E}-05$ & 11.88948192 \\
\hline
\end{tabular}

Table-7 depicts that there is significant role of foreign direct investment from China for industrialization of a country. This study finds that increase in Chinese FDI has contributed to increase the industrial GDP of Nepal. The study reveals that there is positive relationship between Chinese FDI and Industrial GDP. The regression analysis is statistically significant $\left(\mathrm{R}^{2}=0.5781, \mathrm{p}<0.05\right)$. These results indicate that the Chinese FDI has influenced in increase in industrial GDP of Nepal.

\section{Conclusions}

China is recognized as one of the biggest economic development supporter country of Nepal. Nepal took advantage of that situation to seize control of the vital border-pass areas through which most of the trans-Himalayan trade passed. China has been extending 
sympathy, support and assistance. Nepal has been also supporting one China policy and controlling anti-Chinese activities in Nepalese soil. Chinese Government has been committing grant assistance to the Government of Nepal under Economic and Technical Cooperation Program in order to implement mutually acceptable development projects.

Nepal and China have made significant achievement in promoting bilateral cooperation in the fields such as building infrastructure, advancing connectivity and deepening people to people exchanges. There are enormous possibilities for further promoting socio-economic transformation and raising the living standards of the peoples of our countries through enhanced cooperation joint collaboration various areas of mutual interest. China is the second largest trade partner country of foreign of Nepal. Nepal's foreign trade with China has been increasing after 2006s. The ratio of foreign trade of Nepal with China ranges from 7.41 percent to 13.70 percent during the study periods. The export trade of Nepal to China is insignificant in comparison to import trade from China. The trade deficit of Nepal has been expanding during the study period.

Foreign direct investment of Nepal has one of the major components of economic development and prosperity of Nepal. The liberal and open economic policy invites the foreign capital of Nepal. The trends of Chinese FDI have significantly increased. Chinese FDI stands the biggest position of Nepal.Tourism industry is one of the most potential areas for economic development of Nepal. By developing tourism industry, Nepal can boost its economy with small investment. China is the second tourism arrivals country of Nepal. The arrival of Chinese tourists is in increasing trends. The trend shows that China is one of the largest potential countries of tourist arrivals of Nepal. Nepal needs improvement in tourism facility to attract large number of Chinese tourists.

\section{References}

Bi, S. (2021). Cooperation between China and ASEAN under the building of ASEAN Economic Community. Journal of Contemporary East-Asia Studies, 10(1): 83-107. https://doi.org/10.1080124761028.2021.1888410.

Department of Industry. (2020). Summary sheet offoreign direct investment projects in Nepal-Country Wise. Ministry of Industry, Kathmandu: Government of Nepal.

European Union (2017). The economic impact of the comprehensive economic and trade agreement. European Commission's Directive General for Trade, Luxemboug Publications Office.

Fukumoto, M. (2000). Impact of economic and technical cooperation on Northeast Asian countries. APEC Study Center, Institute of Developing Economies, Japan:1-27. 
Mares, D.R. (2000). Exploring the impact of economic cooperation on political and security relations Argentina and Chile.http://www.stimson.org/pubs.cfm?ID=2.(Retrieved on May 20,2021).

MoF. (2010). Economic Survey 2010/11.Ministry of Finance, Kathmandu: Government of Nepal.

MoF. (2014). Economic Survey 2014/15.Ministry of Finance, Kathmandu: Government of Nepal.

MoF. (2019). Economic Survey 2019/20.Ministry of Finance, Kathmandu: Government of Nepal.

MoFA. (2014). Policies of Development Partners.Ministry of Foreign Affairs, Kathmandu: Government of Nepal.

Mukherji, I.N. \&Iyengar, K. (2013). Deepening economiccooperation between India and Sri Lanka.Department of External Relations, Asian Development Bank, Manila.

Noland, M. (January 1996). US-China economic relations. Working Paper 96-6, Institute for International Economics.

Prasad, U.S. (2015). Study of Nepal'seconomic relations with China.The Journal of Development and Administration Studies(JODAS), 23 (1-2): 23-32.

Rahma, M.M., Kim, C. and De, P. (2020). Indo-Pacific Cooperation: What do trade simulations indicate? Journal of Economic Structures, 9(45):1-17. https://doi.org/10.1186/s4008-020-00222-4.

Rahman, Md.T. \& Amin, M.A. (2009). Prospects of economic cooperation in the Bangladesh, China, India and Myanmar region: A quantitative assessment. AsiaPacific Research and Training Network on Trade Working Paper Series. 73: 1-14.

Rana, P.B. and Karmacharya, B. (2014). A connectivity driven development strategy fro Nepal: From a landlocked to a land-linked State. ADB Working Paper Series No.498. Asian Development Bank Institute, Tokyo, Japan.

Verico, K. (2020). How to measure bilateral economic relations? Case of IndonesiaAustralia.LPEM FEB UI Working Paper 056, UniversitasIndenesia, ISSN: 23564008.

Yadav, D. (2021). Is the growth of Sino-Nepal relations reducing Nepal's autonomy? China Brief, a Journal of Analysis and Information,21(5): 27-32. The JAMESTOWN FOUNDATION, Global Research \& Analysis. 